EESTI NSV TEADUSTE AKADEEMIA TOIMETISED. 28, KOIDE GEOLOOGIA. 1979, NR. 1

ИЗВЕСТИЯ АКАДЕМИИ НАУК ЭСТОНСКОИ ССР. ТОМ 28 ГЕОЛОГИЯ, 1979, № 1

\title{
НОВЫЕ НАХОДКИ ИГЛОКОЖИХ ИЗ ВЕРХНЕВИРУСКИХ ОТЛОЖЕНИЙ СЕВЕРНОЙ ЭСТОНИИ
}

В ордовикских отложениях Северо-Запада Русской платформы установлено более 200 видов иглокожих. Бо́льшая часть из них принадлежит к цистоидеям и криноидеям, меньшая - к эокриноидеям, паракриноидеям, парабластоидеям, эдриастероидеям, офиоцистиям, хомостелеям, морским звездам и морским ежам. Стратифицированные находки иглокожих представляют благодарный материал для региональной стратиграфии ордовика Прибалтики и Ленинградской области, для межрегиональных корреляций, а также для палеоэкологических исследований.

В этой связи представляют интерес новые находки иглокожих (преимущественно скелетных остатков цистоидей и криноидей) из верхней половины вируской серии (среднего ордовика), которые получены при растворении и отмывании послойно отобранных образцов из разрезов скважин, а также из обнажений (рис. 1). В изученной коллекции, насчитывающей более тысячи разрозненных элементов скелета, обнаружены многочисленные членики стеблей и рук, а также таблички чашечек. Одни из них принадлежат к известным родам иглокожих Achradocystites, Hemicosmites, Scoliocystis, Herpetocystis, Hoplocrinus, другие относятся к таксонам, родовая принадлежность которых устанавливается впервые. Пять из них - Flabellicystis gen. nov., Oanducystis gen. nov., Rugulosocrinus gen. nov., Rookuelacrinus gen. nov. и Fossulacrinus gen. nov. описаны в настоящей статье. Род Fossulacrinus установлен не только в скважинах Северной Эстонии, но и в скважинах Юго-Восточной Латвии, где он обнаружен на более высоком стратиграфическом уровне, чем в Северной Эстонин.

K родам Flabellicystis и Oanducystis отнесены новые виды телескопических стеблевых члеников цистоидей с флабеллятным морфофункциональным типом сочленения. Эти два рода установлены также в верхнем ордовике (таймырском горизонте) Центрального Таймыра. К родам Rugulosocrinus и Rookuelacrinus принадлежат неизвестные ранее членики стеблей криноидей, которые относятся к розеллиальному морфофункциональному типу. Оба рода, по-видимому, генетически не связаны между собой и принадлежат к разным адаптивным типам, примыкающим к Apertocrinidae, для которых

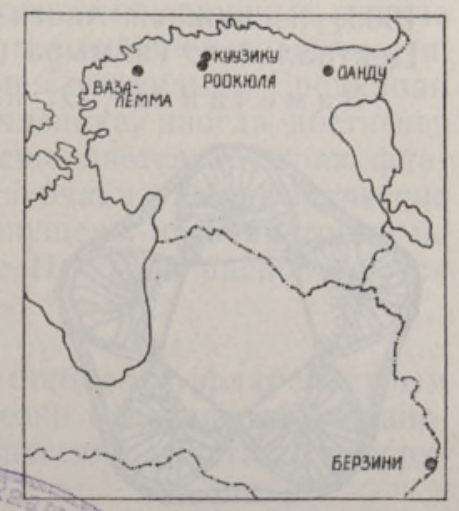

Рис. 1. Местонахождения иглокожик duslik इ2 
характерно направленное уменьшение полости осевого канала, сопровождающееся развитием пятилопастной розетки лигаментного поля. Род Fossulacrinus представлен в коллекции новым видом, для которого характерен редко встречающийся у стеблей криноидей буллиальный морфофункциональный тип сочленения члеников. Подобный тип сочленения описан у ордовикских криноидей Сибири, Таймыра и СевероВостока CССР (родов Mirabilicrinus и Kalgacrinus) и Казахстана (род Ramulicrinus).

Описанный Г. Стукалиной новый материал коллекционирован Л. Хинтс в 1970-1971 гг. в процессе макрофаунистического и стратиграфического изучения среднеордовикских отложений Северной Эстонии. Расчленение изученных разрезов, замечания о фациальной приуроченности и стратиграфическом значении описанных пяти видов иглокожих сформулированы Л. Хинтс.

Оригиналы описанных иглокожих, в том числе и голотипов, хранятся в Институте геологии АН ӘССР (г. Таллин) под каталоговыми номерами Ес $1731-1750$.

\section{Описание иглокожих}

\section{Стеблевые остатки цистоидей}

\section{Genus incertae familia}

Род Flabellicystis Stukalina, gen. nov.

Название рода от flabellum (лат.) - веер.

Типовой вид. Flabellicystis kuusikuensis Stukalina, gen. et sp. nov;; оандуский горизонт $\left(\mathrm{D}_{\mathrm{III}}\right)$, Северная Эстония.

О пис ание. Телескопические ширококанальные стебли, $d_{c}>2 / 3 D$. Шовные линии пентамеров отчетливые на сочленовной и неотчетливые на боковой поверхности. Тип сочленения члеников - флабеллятный (рис. 2). На нижней поверхности сочленения члеников флабелла трехлопастная, узкая. Боковые лопасти симметричные, пологие; срединная лопасть острая, очень короткая. Периферические участки сочленовной поверхности, примыкающие к флабеллам, резко от них отграничены, приподняты и имеют полукруглую форму. Поверхность периферических участков, также как и поверхность флабеллы, испещрена зубчиками, расположенными веерообразно. Участки поверхности сочленения, примыкающие к шовным линиям, резко опущены.

С ост а в. Типовой вид и $F$.tscherkesovae (Yeltyschewa et Stukalina, 1963) из нижней части верхнего ордовика (таймырского горизонта) Центрального Таймыра (см. Елтышева, Стукалина, 1963).

3 а м е ч ания. От известных цистоидных стеблей с флабеллятным

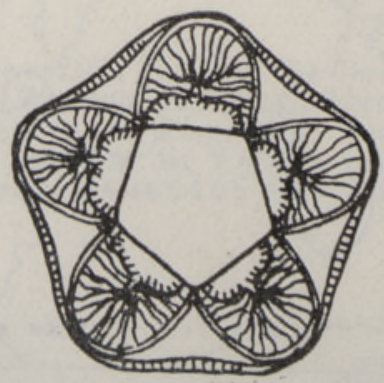
типом сочленения члеников новый вид резко отличается сложным замком сочленения члеников.

Р аспространение. Оандуский горизонт в Северной Эстонии, таймырский горизонт на Центральном Таймыре.

Рис. 2. Схематическое изображение поверхности сочленения члеников стеблей Flabellicystis Stukalina, gen. nov. 
Flabellicystis kuusikuensis Stukalina, gen. et sp. nov.

Таблица, фиг. 1

Название вида по местонахождению в скв. Куузику.

Гол о ти п. Фрагмент стебля Ес 1731, таблица, фиг. 1. Скв. Куузику, гл. 10,70-10,74 $м$; оандуский горизонт $\left(\mathrm{D}_{\mathrm{III}}\right)$.

Ма тер и ал. Три фрагмента стебля хорошей сохранности.

О пи санин. Членики, образующие стебель, пятигранные, телескопические, с нависающим неровным нижним краем. Углы члеников подчеркнуты свисающими каплевидными выступами.

Пятигранный осевой канал очень широкий, $d>2 / 3 D$. Қаждый членик состоит из пяти плотно сросшихся пентамеров. Шовные линии между ними на поверхности сочленения отходят от углов осевого канала; на боковой поверхности едва заметные, продольные прямые линии швов выделены рельефным пережимом. Сочленение члеников флабеллятное. Замок сочленения сложный, распадающийся на пять симметричных участков соответственно числу пентамеров, слагающих членик. В пределах каждого участка имеется система выступов и углублений, поверхность которых испещрена веерообразно расположенными зубчиками. При этом выступам нижней сочленовной поверхности членика соответствуют по конфигурации и размерам углубления верхней сочленовной поверхности.

Размеры, мм: $D-6-7 ; h=1 / 3$ и $<1 / 3 D$.

С р а в н е н ие. От Flabellicystis tscherkesovae (Yelt. et Stuk., 1963), новый вид отличается высокими члениками и особенностями строения их боковой поверхности. Для описываемых форм характерны каплевидные нависающие выступы на углах члеников, в то время как у $F$. tscherkesovae боковая поверхность гладкая и слегка выпуклая.

Р а сп р ост р а н н ие. Оандуский горизонт (D $\left.\mathrm{D}_{\mathrm{III}}\right)$ Северной Эстонии.

Местон ахожд ени е. $\mathrm{D}_{11} \mathrm{O}^{3}(?):$ скв. Куузику, гл. $10,66-10,70 \mu$ стебля длиной 25 м..

\section{Род Oanducystis Stukalina, gen. nov.}

Название рода по оандускому горизонту.

Т и п о в о й в ид. Oanducystis excisus Stukalina, gen. et sp. nov.; Кейлаский $\left(\mathrm{D}_{\text {II }}\right)$ и оандуский (DII) горизонты, Северная Эстония.

О пи сание. Телескопические ширококанальные стебли, $d_{c}={ }_{1}^{1}{ }_{3} D$. Шовные линии едва заметны на поверхности сочленения члеников. Тип сочленения члеников - флабеллятный. Трехлопастные, крупные, резкие флабеллы (рис. 3) занимают бо́льшую часть сочленовной поверхности. Боковые лопасти симметричные, полукруглые, выпуклые. Срединная лопасть длинная, острая, направлена в угол членика, иногда достигает края членика. Вершина срединной лопасти расщепляется. По краю флабелл располагаются короткие радиальные зубчики. Периферические имеют. Края члеников рельефные, приподнятые. По краям располагаются редкие, очень короткие, крупные зубчики.

С ост ав. Типовой вид.

С р в нен ие. От известных цистоидных стеблей с флабеллятным типом сочленения члеников описанный вид резко отличается особенностями строения крупных флабелл и периферических участков, поверхность которых не имеет ребристости. 

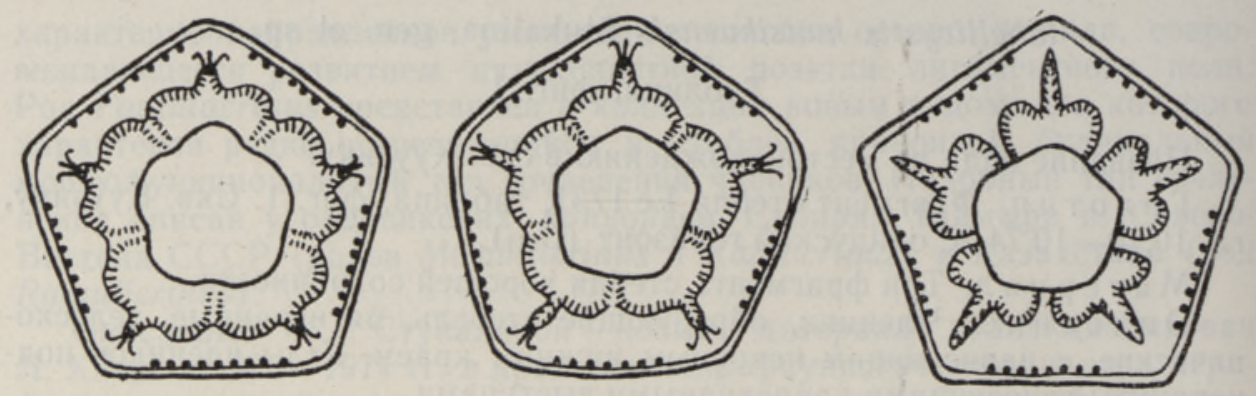

Рис. 3. Схематические изображения поверхностей сочленения члеников стеблей Oanducystis Stukalina, gen. nov.

Р а сп р ост р а н е н е. Кейлаский и оандуский горизонты в Северной Эстонии, таймырский горизонт на Центральном Таймыре.

Oanducystis excisus Stukalina, gen. et sp. nov.

Таблица, фиг. $2-6$

Название вида от excisus (лат.) - вырезной.

Г ол о т п. Фрагмент стебля Ес 1733, таблица, фиг. 3. Западная Эстония, пос. Вазалемма (старый карьер за автобазой); вазалеммаская пачка $\left(\mathrm{D}_{\mathrm{II}-\mathrm{III}} \mathrm{V}\right)$.

$M$ а тери ал. 12 стеблевых фрагментов хорошей сохранности.

О пи с ание. Членики отчетливой пятигранной формы, телескопические, с нависающим неровным краем. На углах члеников наблюдаются свисающие выступы.

Осевой канал широкий, пятиугольный, $d_{c}=1 / 3 D$. Членики состоят из пяти плотно сросшихся пентамеров. Шовные линии между ними едва заметны только на поверхности сочленения члеников. Сочленение члеников флабеллятное. Флабеллы трехлопастные, крупные, рельефные, занимают бо́льшую часть сочленовной поверхности члеников. Боковые лопасти симметричные, выпуклые, срединная лопасть острая, почти достигает края члеников, вершины ее расщепляются. По краю флабелл располагаются короткие радиальные зубчики. Периферические участки поверхности сочленения погруженные, для них характерно отсутствие ребристости. Края члеников приподнятые, рельефные, по краю равномерно распределяются очень короткие грубые зубчики.

Размеры, мм: $D-5-8 ; h=1 / 3$ и $<1 / 3$.

С р а внени е. См. сравнение рода.

Р а сп ростр н ен ие. Пяэскюлаская пачка кейлаского горизонта $\left(\mathrm{D}_{\mathrm{II}} \beta \mathrm{P}\right)$, вазалеммаская пачка $\left(\mathrm{D}_{\mathrm{II}-\mathrm{III}} \mathrm{V}\right)$, верхняя часть оандуского горизонта (DIII) в Северной Эстонии, таймырский горизонт на Центральном Таймыре.

Местонахождение. $\mathrm{D}_{\text {II }} \beta \mathrm{P}$ : пос. Вазалемма, скв. № 772, гл.

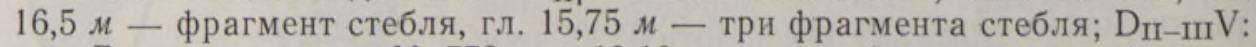
пос. Вазалемма, скв. № 772, гл. 13,10 м - три фрагмента стебля, гл. 13,0 м - фрагмент стебля, гл. $12,7 \mu$ - три фрагмента стебля, гл. $12,25 \mu$ — три фрагмента стебля; скв. № 727, гл. 10,8 - - три фрагмента стебля; старый карьер (за автобазой) - 1 экз.; $\mathrm{D}_{\mathrm{III}}\left(\right.$ ? $\left.\mathrm{D}_{\mathrm{II}} \mathrm{O}^{3}\right)$ : скв. Куузику, гл. 10,66-10,70 м- три фрагмента стебля. 


\section{Стеблевые остатки криноидей}

\section{Группа Pentamerata Stukalina, 1966 \\ Отряд Angulata Stukalina, 1967 \\ Genus incertae familia}

Род Rugulosocrinus Stukalina, gen. nov.

Название рода по типовому виду.

Т и п о во й в ид. Rugulosocrinus rugulosus Stukalina, gen. et sp. nov.; Оандуский горизонт ( $\left.\mathrm{D}_{\mathrm{III}}\right)$, Северная Эстония.

О пи с а ни е. Членики имеют сегментированное строение. Шовные линии на боковой поверхности проксимальных члеников прямые, дистальных - зигзагообразные. Тип сочленения члеников - розеллиальный. Осевой канал и лигаментное поле пятилопастные, $d_{c}=1 / 30$. Лопасти лигаментного поля рельефные, широкие, полукруглые. Края члеников и боковая поверхность гофрированы в грубые резкие складки.

С ост а в. Типовой вид.

3 a м е ч ания. От известных криноидных стеблей с розеллиальным типом сочленения члеников резко отличается характером ребристости поверхности сочленения.

\section{Rugulosocrinus rugulosus Stukalina, gen. et sp. nov.}

Таблица, фиг. 7-10

Название вида от rugulosus (лат.) - морщинистый.

Г оло ти п. Фрагмент стебля Ес 1740, таблица, фиг. 10. Скв. Роокюла, гл. 39,53-39,60 $м$, оандуский горизонт ( $\left.\mathrm{D}_{\text {III }}\right)$.

Матери ал. В коллекции имеется около 60 отдельных члеников и небольших обломков стеблей хорошей сохранности.

О пи сание. Сужающиеся в дистальном направлении стебли состоят из выпуклых высоких члеников с характерной моршинистой боковой поверхностью. Складки-морщины с боковой поверхности переходят на сочленовную, где выполняют функцию ребер. Членики состоят из пяти табличек-пентамеров. В дистальных члениках пентамеры располагаются ступенчато, в проксимальных образуют сплошной горизонтальный поясок. Резкие линии швов наблюдаются на сочленовной и на боковой поверхностях. Тип сочленения члеников - розеллиальный. Осевой канал пятилопастный, $d=1 / 3$ и $<1 / 3 D$. Лигаментное поле (ареола) также пятилопастное, по расположению лопасти ареолы не совпадают с лопастями осевого канала. Строение проксимальных члеников отличается от строения дистальных. Проксимальные членики низкие ( $h: D=1: 6$ и $1: 7)$ с широким осевым каналом. Лигаментное поле с хорошо очерченными рельефными широкими лопастями распространяется на бо́льшую часть сочленовной поверхности. Края сочленовной поверхности собраны в высокие грубые складки, гребни которых по отношению к лопастям лигаментного поля располагаются перисто. Дистальные членики высокие, бочонкообразные $(h: D=3: 4)$. Осевой канал у дистальных члеников значительно у́же и равен или меньше $1 / 3 D$. Лигаментное поле располагается в самом центре сочленовной поверхности, рельефные складки более высокие и резкие.

Размеры, мм: $D$ от 0,8 до 4 .

С р а внени е. Описываемый вид пока единственный в составе рода Rugulosocrinus. Его отличительными признаками служат особенности строения боковой поверхности. 
Р аспространение. Оандуский горизонт (DIII) Северной Эcтонии.

М ес то н а хо жд е н и е. $\mathrm{D}_{\text {III }}$ сквв. Куузику, гл. $14,40-14,50$ м -5 экз.; скв. Роокюла, гл. 39,42-39,53 м- 11 экз., гл. 39,53-39,60 $м-35$ экз., гл. $39,60-39,72 \mu-4$ экз., гл. 39,80-39,90 $м-3$ экз., гл. 39,90$39,98 \mu-1$ экз., гл. 41,12-41,18 $\mu-1$ экз., гл. 41,54-41,70 $\mu-1$ экз.; $\mathrm{D}_{\mathrm{IIO}} \mathrm{O}^{2}$ : p. Оанду, профиль I (по Р. Мяннилю и М. Рубелю, 1960) - 4 экз., профиль III - 3 экз.

\section{Род Rookuelacrinus Stukalina, gen. nov.}

Название рода по местонахождению в скв. Роокюла.

Т и по вой вид. Rookuelacrinus notabilis Stukalina, gen. et sp. nov.; оандуский горизонт $\left(\mathrm{D}_{\mathrm{III}}\right)$, Северная Эстония.

О п и с ан ие. Членики имеют сегментированное строение. На сочленовной поверхности шовные линии обнаруживаются как у проксимальных члеников, так и у дистальных. На боковой поверхности прямые линии швов наблюдаются только у дистальных члеников. Тип сочленения члеников - розеллиальный. Осевой канал неширокий $\left(d_{c}<1 / 3=\right)$, неясной формы. Центральную часть сочленовной поверхности занимает неотчетливое углубление пятилопастного лигаментного поля. Поверхность сочленения неровная, складчатая, гребни складок радиальные, нерезкие.

С ост а в: Типовой вид.

Rookuelacrinus notabilis Stukalina, gen. et sp. nov.

Таблица, фиг. $11-17$

Название вида от notabilis (лат.) - заметный.

Голоти п. Фрагмент стебля Ес 1744, таблица, фиг. 14. Скв. Роокюла, гл. 39,72-39,80 м, оандуский горизонт $\left(\mathrm{D}_{\mathrm{III}}\right)$.

Матери ал. В коллекции имеется около 50 хорошей сохранности разрозненных члеников, происходящих из проксимальной и дистальной частей стебля.

О п и с ани е. Стебли, сужающиеся в дистальном направлении, легко запоминаются благодаря своеобразной орнаментации: углы члеников подчеркнуты резковыдающимися рельефными выступами. У нодальных члеников выступы имеют сложный рисунок, каждый из выступов снабжен оттянутыми вниз сосочками. Расположение члеников I-II-I-II-I.

Членики состоят из пяти табличек-пентамеров. Продольные линии швов на боковой поверхности членика подчеркиваются пережимами боковой поверхности. Наиболее отчетливы шовные линии у дистальных члеников. Тип сочленения члеников - розеллиальный. Осевой канал неширокий, заметно суживающийся в дистальном направлении $\left(d_{c}\right.$ всегда $<1 / 3 D)$, форма канала в поперечнике пятиугольная. В вогнутой центральной части сочленовной поверхности располагается углубление пятилопастной лигаментной ареолы; пальцевидные лопасти ее - неотчетливые. Поверхность сочленения между лопастями ареолы и по краю члеников - неровная, складчатая. Гребни складок, имеющие радиальное направление, выражены неодинаково: выделяются крупные резкие гребни, которые чередуются без видимой закономерности с невысокими едва заметными.

Размеры, мм: $D-1-4$.

С р а внени е. Отличительной особенностью описываемых стеблей является строение боковой поверхности. 
Р аспространени е. Средний ордовик, оандуский горизонт (DII) Северной Эстонии.

Местон ахождени е. $\mathrm{D}_{\amalg}$ : скв. Роокюла, гл. $39,72-39,80$ м 21 экз., гл. 39,80-39,90 $м-6$ экз., гл. 39,90-39,98 $м-8$ экз., гл. 39,99$40,02 \mu-10$ экз.

Род Fossulacrinus Stukalina, gen. nov.

Название рода по типовому виду.

Т и по во й вид. Fossulacrinus fossulus Stukalina, gen. et sp. nov.; оандуский горизонт $\left(\mathrm{D}_{\mathrm{III}}\right)$ и низы раквереского горизонта (E) в Северной Эстонии, набалаский горизонт $\left(\mathrm{F}_{1} \mathrm{a}\right)$ в Восточной Латвии.

О пи с ание. Пентамерные членики с четкими линиями швов на сочленовной и боковой поверхностях. Осевой канал узкий $\left(d_{c}<1 / 5 D\right)$, пятиугольный и звездчатый. Тип сочленения члеников - буллиальный. Буллы занимают бо́льшую часть поверхности сочленения пентамеров, слагающих членики. Проксимальные лигаментные ямки, расположенные в основании булл, узкие и глубокие. Дистальные лигаментные ямки крупные, имеют булавовидную форму (рис. 4). По краю булл располагаются тонкие радиальные зубчики. Замкнутые участки поверхности сочленения члеников между буллами, примыкающие к шовным линиям, опущены.

С остав Типовой вид.

3 а м е ч а н я. Буллиальный тип сочленения

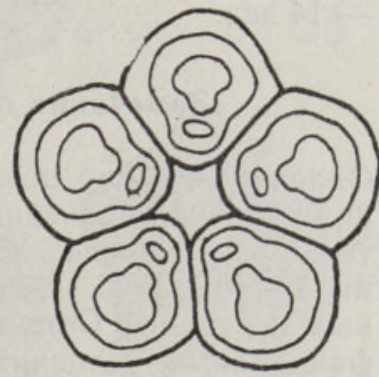

Рис. 4. Схематическое изображение поверхности сочленения члеников стеблей Fossulacrinus Stukalina, gen. nov. члеников стеблевых скелетных образований криноидей в ордовике встречается крайне редко. Он свойствен известным специализированным формам ордовикских родов Kalgacrinus, Mirabilicrinus и Ramulicrinus. Ни с одним из них описываемый род, по-видимому, генетически не связан.

Отличительные особенности рода Fossulacrinus gen. nov. относятся в первую очередь к особенностям строения булл.

\section{Fossulacrinus fossulus Stukalina, gen. et sp. nov.}

$$
\text { Таблица, фиг. } 18-20
$$

Название вида от fossula (лат.) - ямочка.

Голоти п. Фрагмент стебля Ес 1749; таблица, фиг. 19, Юго-Восточная Латвия, скв. Берзини, гл. 431,1 м, набалаский горизонт (F $\mathrm{F}_{\mathrm{I}}$ ).

М а те р и ал. Несколько небольших обломков и отдельных члеников хорошей сохранности.

О пи с а н е. Пятиугольные членики пентамерного строения с четкими линиями швов на поверхности сочленения и боковой поверхности. Боковая поверхность члеников гладкая, слегка выпуклая, нанбольшая степень выпуклости наблюдается на углах члеников.

Сочленовная поверхность члеников делится шовными линиями на пять симметричных участков соответственно числу пентамеров. Бо́льшую часть каждого пентамера занимает овальная булла. Проксимальные лигаментные ямки в основании булл щелевидные, глубокие. Дистальные лигаментные ямки крупные, булавовидной формы. Дистальные и проксимальные лигаментные ямки обычно изолированы, но у некоторых экземп- 
ляров соединены. По краю булл располагаются тонкие радиальные зубчики. Замкнутые участки поверхности сочленения члеников между буллами, примыкающие к шовным линиям, опущены.

Размеры, мм: $D-0,7-2 ; h-$ от $1 / 4$ до $1 / 3$.

Р аспростр анение. Оандуский горизонт ( $\left.\mathrm{D}_{\text {III }}\right)$ и низы раквереского горизонта (E) в Северной Эстонии, набалаский горизонт (F $\mathrm{F}$ ) в Юго-Восточной Латвии.

Местон ахо ждени е. $\mathrm{D}_{\text {II: }}$ скв. Куузику, гл. 14,95-15,0 гл. 12,65-12,70 $м-4$ экз.; скв. Роокюла - гл. $39,72-39,80 \mu-2$ экз., гл. 39,90-39,98 $м-3$ экз., гл. 39,90-40,0 $\mu-1$ экз., гл. 40,06-40,12 $\mu$ 4 экз., гл. 40,57-40,67 $м-3$ экз.; р. Оанду, профиль III - 1 экз.; Е: скв. Роокюла, гл. 38,00-38,04 $м-7$ экз.; F 1 a: скв. Берзини, гл. 431,1 $\boldsymbol{\mu}$ -14 экз.

\section{Замечания о распространении описанных иглокожих}

Описанные выше новые роды и виды иглокожих встречены в отложениях верхней половины вируской серии, для которых характерен сравнительно изменчивый литологический и фаунистический состав (см. Мянниль, 1958, 1960, 1966; Рыымусокс, 1970; Пылма, 1973). Среди описанных цистоидей Oanducystis excisus приурочен к весьма специфическим фациальным условиям. Наиболее древние его находки происходят из скрытокристаллических сгустковых известняков (см. Пылма, 1973) пяэскюлаской пачки кейлаского горизонта $\left(\mathrm{D}_{I I} \beta \mathrm{P}\right)$. Но особенно характерен

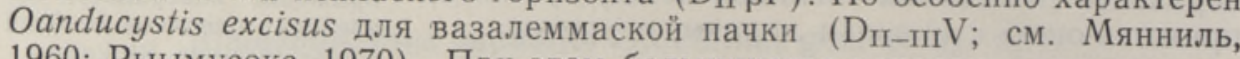
1960; Рымусокс, 1970). При этом большинство находок данного вида

Фиг. 1. Flabellicystis kuusikuensis Stukalina, gen. et sp. nov. голотип, Ec $1731 ; a-$ верхняя поверхность сочленения, 6 - поверхность стебля сбоку, в - нижняя поверхность сочленения. Скв. Куузику, гл. 10,70-10,74 м, микрокристаллический глинистый известняк с пиритизированной галькой; $\mathrm{D}_{\mathrm{III}}\left(\right.$ ? $\left.\mathrm{D}_{\mathrm{II}} \mathrm{O}^{3}\right)$. Увел. $4 \times$.

Фиг. 2-6. Oanducystis excisus Stukalina, gen. et sp. nov. $2-$ Ec 1732; $а$ - верхняя поверхность сочленения, б - поверхность стебля сбоку. Скв. Куузнку, гл. 10,66-10,70 $\mu$, микрокристаллический глинистый известняк с пиритизированной галькой; $\mathrm{D}_{\mathrm{III}}\left(\right.$ ? $\left.\mathrm{D}_{\mathrm{III}} \mathrm{O}^{2}\right)$. 3 - голотип, Ес 1733, нижняя поверхность сочленения. Пос. Вазалемма, старый карьер (за автобазой), $\mathrm{D}_{\mathrm{II}-\mathrm{III}} 4$ - Ec 1734, нижняя поверхность сочленения. Скв. Куузику, гл. 10,66-10,70 м (см. фиг. 2). $5-$ Ес $1735 ; a-$ нижняя поверхность сочленения, б - поверхность стебля сбоку. Пос. Вазалемма, скв. № 772 , гл. 13,10 м, цистоидный мзвестняк, $\mathrm{D}_{\mathrm{II}-1 \mathrm{IV}} 6$ - Ec 1736 , верхняя поверхность сочленения. Пос, Вазалемма скв. 772 , гл. 12,7 м, цистондный известняк, $\mathrm{D}_{\mathrm{II}-\mathrm{IIV}}$. Фиг. 3 и 4 увел. $4 \times$, фиг. 2,5 , н $6-5 \times$.

Фиг. 7-10. Rugulosocrinus rugulosus Stukalina, gen. et sp. nov. Поверхности сочленення члеников (a) и члеников сбоку (б): $7-$ Ec 1737, 8 - Ec 1738, 9- Ес 1739, $10-$ голотип, Ес 1740. Скв. Роокюла, гл. 39,53-39,60 м, детритовый карбонатный мергель; $\mathrm{D}_{\mathrm{III}}\left(\right.$ ? $\left.\mathrm{D}_{\mathrm{III}} \mathrm{O}^{2}\right)$. Увел. $10 \times$.

Фиг. 11-17. Rookuelacrinus notabilis Stukalina, gen. et sp. nov. Поверхности сочленения члеников: 11 - Ес 1741,12 - Ec 1742,13 - Ес 1743,14 - голотип, Ес 1744, $15-$ Ec 1745,16 - Ec $1746,17-$ Ec 1747 . Скв. Роокюла, гл. $39,72-39,80$ м, детритовый глинистый известняк с прослоями карбонатного мергеля; $\mathrm{D}_{\mathrm{III}}\left(\right.$ ? $\left.\mathrm{D}_{\mathrm{III}} \mathrm{O}^{2}\right)$. Увел. $10 \times$.

Фиг. 18-20. Fossulacrinus fossulus Stukalina, gen. et sp. nov. 18 - Ec 1748, поверхность сочленения членика. Скв. Роокюла, гл. 39,90-39,98 м, детритовый карбонатный мергель; $\mathrm{D}_{\mathrm{III}}\left(\right.$ ? $\mathrm{D}_{\mathrm{IIIO}}{ }^{2}$ ). 19 - голотип, Ec $1749 ; a$ - поверхность сочленения членика, 6 - поверхность фрагмента стебля сбоку. Скв. Берзини, гл. 431,1 м, известковый мергель; $\mathrm{F}_{1}$ a. $20-$ Ec 1750, поверхность сочленения членика. Скв. Берзини, гл. 431,1 м, известковый мергель; F! а. Фиг, 18 увел, $20 \times$, фиг, 19 и $20-12 \times$. 

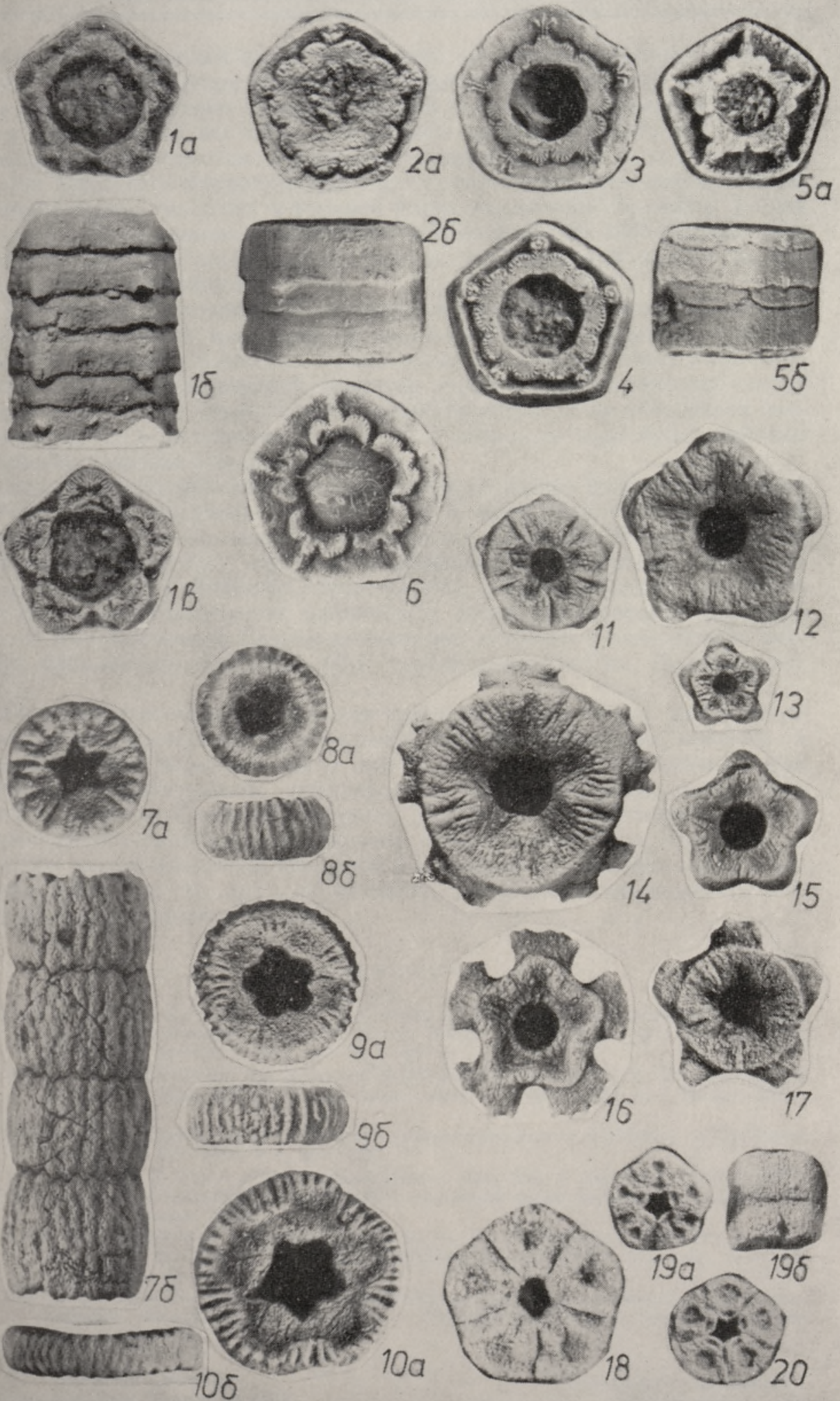

происходит из нижней части этой пачки, из прослоев глинистых детритовых или биоморфных известняков и детритовых мергелей (из отложений предположительно околобиогермной фации) и из прослоев цистоидного известняка. В вертикальном разрезе прослои с Oanducystis excisus многократно чередуются с прослоями биогермов. Кроме того, Oanducystis excisus встречен в микрокристаллических глинистых известняках с пиритизированными гальками в верхней части оандуского горизонта (в скв. Куузику). В последних известняках встречен также Flabellicystis kuusikuensis, который, по-видимому, близок к Oanducystis excisus по фациальной приуроченности.

Криноидеи Rookuelacrinus notabilis и Rugulosocrinus rugulosus происходят из богатых макрофауной (мшанками, брахиоподами, трилобитами) детритовых глинистых известняков и мергелей оандуского горизонта (D III). Литологический характер пород и таксономический состав фауны этой пачки относительно малоизменчивы, и не исключена возможность, что в дальнейшем отмеченные выше два вида будут найдены во многих разрезах Северной Эстонии.

Новый вид Fossulacrinus fossulus имеет не только наибольший диапазон вертикального распространения, но и приуроченность к наиболее разнофациальным отложениям. В разрезах Северной Эстонии этот вид встречен в глинистых мергелях и известняках оандуского горизонта (DIII; совместно с Rookuelacrinus notabilis и Rugulosocrinus rugulosus) и в скрытокристаллических известняках низов раквереского горизонта (Е). В Юго-Восточной Латвии данный вид встречен в известковых мергелях набалаского горизонта ( $\mathrm{F}_{1} \mathrm{a}$; третий комплекс; см. Палма и др., 1977).

Распространение и фациальная приуроченность новых видов иглокожих дает основание предполагать, что Rookuelacrinus notabilis и Rugulosocrinus rugulosus могут иметь корреляционное значение при расчленении и послойном сопоставлении отложений оандуского горизонта в разрезах Северной Эстонии. Возможно, что большая частота встречаемости цистоидей Oanducystis excisus может быть применена в качестве дополнительного признака при выделении нижней части вазалеммаской пачки $\left(\mathrm{D}_{\mathrm{II}-\mathrm{II}} \mathrm{V}\right)$, по возрасту соответствующей сауэской пачке кейлаского горизонта (D $\left.\mathrm{D}_{\mathrm{II}} \beta \mathrm{S}\right)$.

\section{Л ИТЕРА Т Р А}

Елты шев а Р. С., С тук а ли н а Г. А. Стебли ордовикских и нижнесилурийских крннондей Центрального Таймыра, Новой Земли и Вайгача. - Уч. зап. НИИГА. Палеонт. и бнострат., 1963, вып. 2, с. 23-62.

М янн и ль Р. М. Основные черты стратиграфии кейлаского горизонта (D II, ордовик) и Эстонии. - Изв. АН ЭССР, сер. техн. и физ.-мат. наук, 1958 , т. 7, № 3, с. 235246.

М ян н и ль Р. М. Стратиграфия оандуского («вазалеммаского») горизонта, - Тр. Ин-та геол. АН ЭССР, 1960 , V, с. $89-122$.

Мянни ль Р. М. История развития Балтийского бассейна в ордовике. Таллин, 1966.

Р ы м у с ок с А, Стратиграфия вируской и харьюской серий (ордовик) Северной Эстонии. І. Таллин, 1970.

Пыл м а Л. Особенности структурно-фациальных зон Балтийского бассейна в ордовике. - В кн.: Фации и геохимия карбонатных отложений. Тез. докл. Л.-Таллин, 1973 , с. $34-36$.

П ы л а Л., С а р в Л., Хи н тс Л. Расчленение ордовикских отложений разреза скв, Берзини (Юго-Восточная Латвия). - Изв. АН ЭССР, Хим. Геол., 1977, т. 26, № 2, c. $113-121$. 
G. STUKALINA, Linda HINTS

\section{UUSI OKASNAHKSETE LEIDE PÕHJA-EESTI OLEMVIRU SETETEST}

Artiklis on esitatud viie uue okasnahksete perekonna ja liigi (Flabellicystis kuusikuensis, Oanducystis excisus, Rugulosocrinus rugulosus, Rookuelacrinus notabilis ja Fossulacrinus fossulus) kirjeldused ning osutatud liikide stratigraafilise ja geograafilise leviku võimalikule sõltuvusele fatsiaalsetest tingimustest.

\section{G. STUKALINA, Linda HINTS}

\section{NEW FINDS OF ECHINODERMS IN THE UPPER VIRUAN DEPOSITS OF NORTH ESTONIA}

The authors present descriptions of five new genera and species of echinoderms, Flabellicystis kuusikuensis (from the Oandu Stage of North Estonia), Oanducystis excisus (from the Pääsküla Member of the Keila Stage, Vasalemma Member, and from the upper part of the Oandu Stage), Rugulosocrinus rugulosus (from the Oandu Stage), Rookuelacrinus notabilis (from the Oandu Stage) and Fossulacrinus fossulus (from the Oandu Stage and lower part of Rakvere Stage of North Estonia and from the Nabala Stage of East Latvia). The stratigraphical and geographical distribution of the described species probably depends on facial conditions, above all. 